\title{
FINANCIAL BUSINESS CONSULTING IN THE CONDITIONS OF INTERNATIONAL FINANCIAL SPHERE
}

\section{ФІНАНСОВИЙ БІЗНЕС-КОНСАЛТИНГ В УМОВАХ ІНТЕРНАЦІОНАЛІЗАЦЇ̈ ФІНАНСОВОЇ СФЕРИ}

\section{Lyudmila Nechyporuk ${ }^{1}$}

DOI: https://doi.org/10.30525/978-9934-588-15-0-38

Abstract. The purpose of the article is defining the prerequisites for increasing the need for financial business consulting in the internationalization of the financial sector. It is natural for any business organization to operate in the face of uncertainty and risk. It is well known that, with the aim of maximizing profit, it operates in conditions of limited resources (labor, financial, information, tangible and intangible), and, therefore, the problem of minimizing the financing of losses due to the onset of risks, which is more likely in the conditions of internationalization of the financial sphere, is urgent. Methodology. The tasks are solved on the basis of the application of general scientific and special methods of scientific knowledge, among which: systemic and institutional-evolutionary approaches, theories of network and behavioral economics, historical method, methods of analysis and synthesis were applied in the process of generalization of theoretical approaches to the analysis of business risk management organizations. Results. The main risk factor of the financial system in the conditions of internationalization of the financial sector is the spread of features of a market economy as a self-organizing system to the world economy. The second type of risk is due to the network structures of financial and organizational systems, namely: asymmetric distribution of information, which, at first glance, is excessive, but in reality is not accessible to all and is unevenly distributed. In addition, it should be noted that information between the nodes of the network system (financial centers) rotates in real time, resulting in a breach in one part of the system instantly extends to the whole system. Practical implications. With the goal of profit maximization, a business organization operates under conditions of limited

${ }^{1}$ Doctor of Economics, Professor,

Yaroslav Mudryi National Law University, Ukraine 
resources (labor, financial, informational, material and intangible), and, therefore, there is a problem of minimizing the costs of financing these conditions. The recommendations of financial business consulting in the context of internationalization of the financial sector regarding the use of mergers and acquisitions carried out in compliance with the requirements of the law, as well as the rights and legitimate interests of all participants in the process are considered as acceptable instruments of business development worldwide. Value/ originality. Financial business consulting helps to solve the following main tasks: formation of financial policy; conducting financial expertise; search for sources of financial resources; analyzing and improving the current financial performance of business entities; strengthening of financial position, achievement of financial stability and independence of economic entities; optimization of organization's capital management; optimization of financial relations with clients and creditors, with business entities, state bodies; optimization of tax management, accounting and management accounting; implementation of advanced financial management techniques in the face of uncertainty and risk. In the context of the internationalization of the financial sector, consulting on the aspects of financial security of all economic entities: households, enterprises and the state plays an important role. Conditions for achieving financial security of the state affect the regulatory rules to be followed by both households and firms.

\section{1. Ветуп}

Інтернаціоналізації фінансової сфери стимулюється нерівномірністю економічного розвитку та розподілу фінансових ресурсів; недостатністю в більшості країн власних ресурсів для покриття бюджетних дефіцитів, проведенням соціально-економічних перетворень, здійсненням процесів злиття та поглинання компаній і банків, виконання боргових зобов'язань по внутрішніх із зовнішніх запозиченнях. Світова фінансова криза 2008 року привела до відчутного погіршення основних економічних показників у більшості розвинених країн і до глобальної рецесії. В цих умовах, а також з урахуванням циклічності та кризовості економіки, управління фінансами має велике значення для ефективного використання ресурсів організації, забезпечення стабільності і стійкості поточної господарської діяльності організації, а також створення інвестиційних можливостей для іiї розвитку. 
Метою дослідження є визначення передумов посилення потреби у фінансовому бізнес-консалтингу в умовах інтернаціоналізації фінансової сфери. Цілком природньо, що будь-яка бізнес-організація здійснює свою діяльність в умовах невизначеності та ризиків. Як відомо, маючи мету максимізації прибутку, вона працює в умовах обмеженості ресурсів (трудових, фінансових, інформаційних, матеріальних та нематеріальних), а, отже, актуальною є проблема мінімізації фінансування втрат, що обумовлені настанням ризиків, ймовірність яких більшає в умовах інтернаціоналізації фінансової сфери.

\section{2. Фінансовий бізнес-консалтинг \\ в умовах невизначеності та ризиків}

Під фінансовим консалтингом прийнято розуміти комплекс заходів, спрямованих на підвищення ефективності фінансового управління 3 урахуванням використання усіх фінансових ресурсів організації-клієнта. Фінансовий бізнес-консалтинг спрямований на вирімення таких завдань: фінансові стратегічні завдання: максимізація прибутку підприємства, забезпечення інвестиційної привабливості підприємства, забезпечення фінансової стійкості в довгостроковому періоді; поточні цілі (завдання): забезпечення збалансованості надходження грошових коштів (платоспроможності та ліквідності підприємства), забезпечення достатнього рівня рентабельності і продажів за рахунок гнучкої цінової політики і зниження витрат, запобігання банкрутства і відчутних фінансових втрат.

Усі завдання тісно пов'язані між собою, і вирішуються в рамках фінансової політики підприємства, що має такі складові: облікова політика; кредитна політика - політика у взаєминах з банками, або по відношенню до кредитів взагалі; політика щодо управління витратами (метод регулювання витрат, класифікація витрат, частка постійних витрат у собівартості); податкова політика та податкове планування (оптимізація податкових платежів); дивідендна політика; політика управління грошовими коштами (у тому числі оборотними активами); інвестиційна політика (найбільш ефективна з фінансової точки зору).

Потреба у фінансовому бізнес-консалтингу особливо актуалізується в наслідок невизначеності та ризиків в діяльності суб'єктів господарювання. Уточнимо, що ситуація невизначеності характери- 
зується тим, що ймовірність настання результатів рішень або подій у принципі не може бути встановлено. Ситуацію ризику можна схарактеризувати як різновид невизначеності, коли настання тієї чи іншої події ймовірне, причому існує об'єктивна можливість кількісно оцінити відповідну ймовірність [5, с. 21].

Фактори, що породжують невизначеність господарської системи, уточнюють в певному порядку, а саме фактори: «першого порядку зміни в природному середовищі; зміни у виробництві, техніці як природі, створеній людиною; зміни людини як предметно-діяльної істоти; другого порядку - недостатні дані про ці зміни, перешкоди, які виникають у процесі їх перетворення в інформацію. Обмежені можливості їх трансформування у знання; третього порядку - це асиметрія інформації, яка проявляється у грубому, природному чи стратегічному опортунізмі» [7, с. 4]. Невизначеність можна трактувати як недостовірність (ефект «марева»), неоднозначність (ефект «нечіткості», «розпливчастості») [3, с. 34-35].

Існують різні підходи щодо трактування самого поняття «ризик». У теоріях статистичного оцінювання рішень і розпізнання образів під ризиком розуміють математичне очікування функції негативних наслідків (шкоди) при розрахунку оцінки параметрів математичної моделі або структури. Близькими до поняття ризику є небезпека і уразливість, які аналізуються за умов надзвичайних ситуацій техногенного та природного характеру. Небезпека розраховується на основі теорії припущень, а уразливість залежить від ступеня підупадання певного об'єкта під вплив ризикової події.

У цілому, зауважимо, що поняття ризик по-різному трактується в таких галузях знань, де воно $є$ ключовим. Поширеною $є$ така трактова. Ризик - це об'єктивне явище, його вимірювання можна здійснити математичним шляхом за допомогою теорії ймовірності та закону великих чисел.

В умовах невизначеності та ризиків набуває поширення комплексна консультаційна послуга, як перевірка належної сумлінності - Дью Ділідженс (Due Diligence, DueD, DDG), що передбачає вивчення організації, іiі загальної системи управління, фінансового менеджменту, аналіз наявних угод, договорів, фінансових звітів, зобов'язань, інвестиційних можливостей. 
Види проведення Дью Ділідженс:

фінансовий аналіз (financial due diligence), який дає висновок про здатність підприємства приносити дохід забезпечувати прибутковість;

податковий аналіз (tax due diligence) - детальний аналіз податкових ризиків, сум обчислених та сплачених податкових платежів та їх динаміки, показників податкової та (або) бухгалтерської (фінансової) звітності та їх динаміки; факторів, що впливають на формування податкової бази, на основі чого робиться висновок про тяжкість податкового навантаження на підприємство та можливість податкової оптимізації;

правова експертиза (legal due diligence) документів на предмет відповідності діяльності фірми нормативним актам у сфері цивільного, трудового права тощо, в процесі якої надаються рекомендації щодо зміни редакції документації підприємства на відповідність існуючим нормам юриспруденції [1].

3 метою визначення ризиків, що загрожують бізнесу слід здійснити такі кроки: 1) виявлення ризиків: важливим $\epsilon$ визначення факторів та подій, що можуть негативно вплинути на цілі компанії, бо ризики, які не будуть виявлені на цьому етапі не зможуть бути мінімізовані в майбутньому; 2) оцінка ризиків: аналіз ризиків 3 метою визначення найбільш критичних з точки зору вірогідності, втрат і відповідно найбільш пріоритетних, що дозволяє визначити вузький спектр потенціальних ризиків на яких керівництву необхідно фокусуватись; 3) управління ризиками: розробка заходів, що виключають або знижують рівень ризику, визначення попередніх строків впровадження та встановлення відповідальних, залучення додаткових ресурсів.

Уточнимо, що може бути створений спеціальний функціональний відділ з ризик-менеджменту фірми (підприємства), що має працювати як:

інформаційно-аналітичний відділ (аналіз та експертне оцінювання ризиків та прогнозування їх розвитку; інформаційне забезпечення суб'єктів ризик-менеджменту тощо);

відділ методичного забезпечення та планування управління ризиками (розробка методики оцінки та моніторингу ризиків; складання планів; розподіл компетенції тощо);

відділ контролю та моніторингу системи ризик-менеджменту (оцінювання стану функціонування системи управління ризиками та визначення напрямів удосконалення); 
відділ адміністрування ризиків та їх правового забезпечення (розробка програм мінімізації ризиків та їх страхування; робота $з$ претензіями споживачів та партнерів тощо).

Але наявність такого відділу вимагає суттєвого збільшення витрат фірми, тому реалізація функцій ризик-менеджменту може бути передана за межі організації (аутсорсинг). Організації може бути вигідніше (доцільніше) передати систему ризик-менеджменту або її окремі функції (наприклад, ідентифікація та оцінка ризику; управління окремими ризиками тощо) за межи організаційної структури. В практиці ризик-менеджменту такий «субпідряд» називають аутсорсингом управління ризиком (субпідрядниками зазвичай виступають фінансові консультанти, страхові компанії і брокери, банки та інші фінансові організації тощо).

Основні переваги аутсорсингу управління ризиками (Risk management outsourcing): відчутна економія на витратах пов'язаних 3 функціонуванням організаційної системи ризик-менеджменту, бо організація має можливість відмовитись від необхідності включення до штату посад, професійна діяльність за якими, передбачає виконання функцій ризик-менеджменту, що 3 одного боку, заощаджує бюджет організації, а з іншого - дозволяє користуватися послугами висококваліфікованих фахівців.

\section{3. Інтернаціоналізація фінансової сфери}

Інтернаціоналізація фінансової сфери породжує надмірну невизначеність та ризики, що висуває додаткові запити щодо фінансового бізнес-консалтингу. Уточнимо, що інтернаціоналізація фінансової сфери на сучасному етапі розгортається по трьох основних напрямах: 1) інтернаціоналізація фінансових послуг 3 проникненням в економіку країн, що розвиваються, іноземних банків та інших фінансових установ; 2) зростання міжнародних потоків акціонерного капіталу, враховуючи прямі іноземні інвестиції, обсяг яких останнім часом був більше, аніж потоки боргових обов'язків; 3) посилення потоків боргових обов'язків, головними індикаторами яких $є$ рівні процентних ставок і валютні курси.

Все більш поширеними стають ідеї зміцнення симбіозу національних систем та міжнародної фінансової системи, відповідно до яких передбачається: 
- більш ефективний контроль над економічною політикою окремих країн на основі принципів максимальної відкритості та доступності відповідної макроекономічної та фінансової інформації;

- моніторинг тенденцій в економічних взаємовідносинах між країнами окремих регіонів;

- створення більш ефективних механізмів задля врегулювання проблем, що пов'язані із заборгованістю на мікрорівні економічного життя, зокрема прийняття більш досконалих законів про банкрутство на національному рівні;

- послідовна, обгрунтована та точно вивірена політика лібералізації руху капіталів, яка повинна забезпечити розширення доступу на міжнародний ринок капіталів багатьом країнам;

- краща взаємодія національних та міжнародних інститутів кредитно-фінансової політики;

- посилення кредитної та стабілізаційної потужності міжнародних фінансових організацій, у тому числі сумарного об'єму їхніх фінансових ресурсів [4, с. 464].

Прикметою інтернаціоналізації фінансової сфери може бути капітал, що функціонує за кордонами країни походження в обсягах накопичених іноземних активів, до складу яких залучають прямі та портфельні інвестиції (акції та боргові цінні папери), вимоги по банківських позиках, міждержавних кредитах тощо.

Вивезення капіталу за межі національних кордонів є найпотужнішим фактором поглиблення фінансової глобалізації, зближення рівнів розвитку різних країн, створення атмосфери взаємної довіри і поваги інтересів у міжнародному середовищі. Слід зазначити, що експорт капіталу можливий лише за наявності в господарстві країни-експортера значних грошових заощаджень (нагромаджень), які здатні трансформуватися в капітал як для внутрішніх, так і для зовнішніх інвестицій. Без створення солідних вільних фінансових ресурсів у певному колі країн фінансова глобалізація розвиватися не може.

Виводячи капітал за національні кордони, його власники керуються такими мотивами:

а) зниження собівартості та підвищення конкурентоспроможності продукції внаслідок диверсифікації виробництва, збільшення ефек- 
тивності корпорації та економії на масштабах, раціоналізації окремих операцій, зменшення податкового навантаження;

б) здобуття доступу до природних чи людських ресурсів для надійного забезпечення власного виробництва;

в) подолання імпортних бар'єрів та завоювання нових ринків збуту своєї продукції, здобуття контролю над цими ринками, диверсифікації форм конкурентної боротьби на них;

г) завоювання перспективо вигідної позиції відносно джерел ресурсів, ринків збуту, ресурсних потоків тощо, у тому числі - і з метою створення підгрунтя для здійснення політичного впливу на країнуреципієнта на державному рівні;

д) досягнення цілі економічного знищення реальних або потенційних конкурентів.

Визначальний вплив на міжнародний рух капіталів здійснюють показники прибутковості активів, у які робляться вкладення. Конкуренція за залучення прямих іноземних інвестицій на міжнародних ринках капіталів вимагає від національних урядів запровадження спеціальних сприятливих умов для діяльності іноземних інвесторів.

Водночас проникнення до національної економіки іноземного капіталу може спричинити неоднозначні наслідки, створюючи низку загроз національній економічній безпеці країни-реципієнта. Слід особливо наголосити на тому, що в переважній більшості випадків ці загрози не $є$ умисними, а випливають з реалізації основної цільової функції іноземної інвестиції - забезпечення максимальної прибутковості використання активів. Загрози обумовлені і особливістю інвестицій.

Постійне збільшення швидкості фінансових потоків внаслідок розвитку систем електронних трансакцій, наявність у розвинених країнах світу значного фіктивного капіталу у вигляді цінних паперів, які не мають реального забезпечення, уможливлюють значні «припливи» та «відпливи» спекулятивних капіталів та дають підстави й надалі очікувати посилення загроз економічній безпеці держави внаслідок дії цього чинника.

Проте значні загрози можуть виходити також і від прямих іноземних інвестицій. Насамперед, вони можуть вести до посилення залежності економіки від іноземного капіталу. Передусім це стосується інвестицій у підприємства, які здійснюють переважно експортне виробництво в 
рамках схем виробничої кооперації ТНК. Погіршення світової економічної кон'юнктури вестиме до згортання цих виробництв незалежно від економічного становища всередині країни.

ТНК формують міжнародні виробничі, науково-технічні зв'язки і співробітництво, виступають основними суб'єктами іллегалізації міжнародної економіки, враховуючи значну кількість випадків недобросовісної конкуренції, недостатню прозорість внутрішньо корпоративного руху факторів виробництва та продуктів праці, що дає можливість приховувати певну частину прибутку, одержану у країні перебування дочірньої компанії. ТНК цілком байдужі до економічного комплексу країни в цілому і орієнтуються на включення в систему міжнародного розподілу праці лише високоприбуткових сегментів економіки. Наслідком такого підходу є занепад менш дохідних галузей економіки, що посилює структурні диспропорції та конфлікт інтересів у національній економіці між рівнями підприємства, регіону та національної економіки.

Небезпечними у цьому сенсі $\epsilon$ також виробництва, які повністю забезпечуються імпортними комплектуючими і не мають ні власних технологій, ні можливості диверсифікувати джерела постачання.

Потрібно усвідомлювати, що прямі інвестиції виступають для зарубіжних компаній способом завоювання ринків товарів та послуг, що створює певну зацікавленість у здобутті контролю над потенційними конкурентами - аж до припинення діяльності останніх. Внаслідок цього діяльність підприємств з іноземними інвестиціями цілком може вести до витіснення товарів національного виробництва з ринку, «відтягування» на себе дефіцитних ресурсів, «витискання» з ринку вітчизняних капіталів. Важливо, що такі процеси здійснюватимуться цілком природними ринковими засобами внаслідок різних «вагових категорій» зарубіжних корпорацій та вітчизняних підприємств.

Вагому загрозу може становити відтік прибутків з країни. Зрештою, транснаціональний капітал з метою захисту своїх інтересів може здійснювати потужний політичний тиск на країну-реципієнта, змушуючи іiї вживати невигідні для національного виробника чи національної економічної безпеки заходи економічної політики, спонукаючи до зовнішньополітичних кроків, які не завжди відповідають національним інтересам.

Як засвідчує міжнародна практика, є цілком припустимими i навіть необхідними вимоги до іноземних інвестицій щодо збереження 
обсягів зайнятості, профілю підприємства, розширення експортного виробництва, кадрової політики, впровадження технологій, реінвестування прибутків, екологічних нормативів тощо. У багатьох країнах державою контролюється трансфертне ціноутворення у відносинах між дочірніми та материнською компаніями ТНК, обмежується доступ іноземців до фондового ринку, ринку землі.

Головним ризикоутворюючим фактором фінансової системи в умовах інтернаціоналізації фінансової сфери є поширення ознак ринкової економіки як самоорганізуючої системи на все світове господарство. Другий тип ризиків обумовлений мережевими структурами фінансових і організаційних систем, а саме: несиметричним розподілом інформації, яка, лише на перший погляд, $є$ надмірною, а в реальній дійсності доступна не для всіх і розповсюджується нерівномірно. До того ж слід зазначити, що інформація поміж вузлами мережевої системи (фінансовими центрами) обертається в режимі реального часу, внаслідок чого порушення в одній частині системи миттєво поширюється на всю систему.

Ризик фінансової нестабільності може бути суттєво знижений за допомогою раціональної макроекономічної політики на національному рівні, тісного міжнародного співробітництва та подальшого вдосконалення архітектури світової фінансової системи, спрямованих перш за все на попередження кризових явищ.

\section{4. Консалтинг в умовах інтернаціоналізації фінансової сфери}

В умовах інтернаціоналізації фінансової сфери важливу роль відіграє консалтинг щзодо аспектів фінансової безпеки всіх суб'єктів економіки: домогосподарства, підприємства та держави. Умови досягнення фінансової безпеки держави впливають на регуляторні правила, яких мають дотримуватися як домогосподарства, так і фірми. Тому консалтинг щодо аспектів фінансової безпеки має грунтуватися на усвідомленні сутності та складових саме фінансової безпеки держави, яка має такі характеристики: 1) це - важлива складова економічної безпеки держави, що базується на незалежності, ефективності і конкурентоспроможності фінансово-кредитної сфери; 2) це стан захищеності та стійкості розвитку фінансових відносин, що формуються на різних рівнях і в різних сферах фінансової системи та досягається шляхом реалізації заходів по нейтралізації як внутрішніх, так і зовнішніх загроз. 
Внутрішні загрози фінансовій безпеці України переважно породжуються:

дезорганізацією фінансово-кредитної системи та послабленням iii регулятивних функції в сфері формування та виконання бюджету, цілеспрямованого інвестування пріоритетних галузей економіки, протидії інфляції, превенції втечі капіталу за кордон та створення передумов для розвитку підприємництва;

звуженням внутрішнього фінансового ринку та послабленням ролі внутрішніх соціально-економічних стимуляторів економічного зростання;

криміналізацією економічних відносин, зростом корупції;

збільшенням фінансових утрат в наслідок посилення соціальної напруженості в економічній сфері.

Серед основних причин виникнення зовнішніх загроз фінансової безпеки в умовах інтернаціоналізації фінансової сфери слід, на наш погляд, виокремити:

3 метою оптимізації фінансового стану підприємства можуть утворюватися різні форми фінансово-промислових корпоративних об'єднань (ФПКО), що визначає розвиток процесу транснаціоналізації світового господарства на фоні зростання автономізації субдержавних суб'єктів (ТНК, ТНБ та ін.), що мають значну фінансову владу та істотний вплив на господарські комплекси окремих країн, і посилення конкуренції на міждержавному рівні;

постійне зростання як самої маси, так і мобільності капіталів, що сприяє концентрації фінансових ресурсів як на макро-, так і на мегарівнях, в умовах посилення залежності національних економік від іноземного короткострокового спекулятивного капіталу, що зумовлює вразливість їх фінансових систем;

високу ступінь мобільності та взаємозалежності фінансових ринків на основі новітніх інформаційних технологій;

різноманіття фінансових інструментів та постійний їх динамізм;

нестійкість світової фінансової системи, виникнення кризових явищ, неспроможність сучасних фінансових інститутів (світових включно) ефективно їх контролювати.

взаємоперетинання внутрішньої та зовнішньої політики держав, які все більше залежать від світових фінансів, що спричиняє втрату національних пріоритетів у фінансовій сфері через просування інозем- 
ними партнерами вигідних переважно для них економічних проектів та фінансових програм.

Зауважимо, що в науковій літературі визнано, що проявом концентрації і централізації капіталу є формування різноманітних форм фінансово-промислових корпоративних об'єднань (ФПКО), які можуть бути як національними, так і транснаціональними. Розрізняють як позитивні ефекти ФПКО: можливість масштабного виробництва товарів і надання послуг; сприяння розвитку галузей економіки і регіонів держави; створення нових робочих місць; ефективне використання ресурсів; підвищення інвестиційної активності; перспектива фінансування масштабних проектів, так і негативні, що напряму обумовлені визначеними перевагами, а саме: концентрація значних фінансових ресурсів, що допускає їх контроль над галузями та регіонами та забезпечує можливість впливати на темпи розвитку національної економіки.

Метою створення ФПГ можна вважати: підвищення ефективності діяльності окремих підприємств - учасників групи на основі об'єднання та раціонального використання матеріальних, технологічних, фінансових та інформаційних ресурсів; розвитку діючих і створення нових економічних відносин; реалізації інвестиційних проектів; підвищення конкурентоздатності продукції; розширення ринків збуту та створення робочих місць; проведення активної товарної політики; забезпечення безперебійних поставок і збуту продукції; забезпечення структурної перебудови національної економіки, підвищення ефективності її управління, планування і регулювання; підвищення експортного потенціалу i конкурентоспроможності українських підприємств [2, с. 133].

В Україні господарських структури підпадають за неформальними ознаками під визначення промислово-фінансових груп, загальний інтеграційний ефект від яких досягається від двох видів синергійного ефекту - операційного (ефект агломерації, економія витрат на проведення НДДКР, ефект комбінування i комплексного використання ресурсів, збільшення розміру ринкової ніші) і фінансового (створення податкових щитів, можливість купівлі компанії за ціною нижчою від балансової, фінансова диверсифікація) а також формування інноваційно-інвестиційного потенціалу [6, с. 119-120].

Фінансові групи, що здійснюють діяльність у сфері банківських, страхових послуг та на ринку цінних паперів, у широкому розумінні являє 
собою об'єднання юридичних осіб, пов'язаних між собою через механізм контролю або впливу. Вони часто діють у декількох юрисдикціях і можуть поєднувати кілька відносно незалежних юридичних осіб. Для досягнення синергізму та економії коштів фінансові групи використовують ряд юридичних осіб і структур і користуються відмінностями в їхньому оподаткуванні, контролі й регулюванні у різних секторах фінансового ринку та в різних країнах. Відповідно до стандартів IAIS існують різні види фінансових груп, їх спектр - від національних однорідних груп до міжнародних неоднорідних фінансових конгломератів.

Система регулювання та нагляду за фінансовими групами розподіляється на дві точки зору щодо їхньої сутності:

- фінансова група вважається однією диверсифікованою економічною одиницею, яка об'єднує ризики.

- фінансова група складається з безлічі окремих юридичних осіб, виходячи з чого існуючі механізми контролю можна розділити на дві групи.

При комплексному (консолідованому) підході вимоги до капіталу пред'являються до консолідованих активів і пасивів на рівні материнської компанії. Передбачається, що ці активи і пасиви вільно обертаються в межах групи. Зважений на ризик агрегований підхід передбачає, що вимоги до капіталу застосовуються до окремих регульованих компаній у межах фінансової групи. Основними результатами загальносвітових дискусій про специфіку злиттів та поглинань M\&A (Mergers \& Acquisitions) у сучасній економіці, про різні форми державного регулювання даних процесів $є$ визначення, що це непросте об'єднання декількох майнових комплексів (підприємств) і трудових колективів й специфічне явище сучасної економіки пов'язане з корпоративною організацією капіталу з метою створення умов для економічної концентрації. Злиттям (merger) називається об'єднання двох компаній з метою створення однісї, при цьому компанія, що поглинає, приймає зобов'язання та активи компанії, що поглинається. Для визначення угод такого типу використовується термін «статутне злиття» (statutory merger), що являє собою злиття двох компаній, в якому компанія-ціль стає дочірньою структурою чи частиною «дочки» материнської компанії та субсидіарне злитті (reverse subsidiary merger), при якому дочірнє підприємство материнської компанії вливається до компанії-цілі.

Злиття відрізняється від консолідації (consolidation), що являє собою об’єднання підприємств, в якому компанії зливаються для утворення 
абсолютно нової компанії, тобто створюється нова юридична особа. Термін «поглинання» (takeover) є більш невизначеним та іноді має відношення лише до недружніх угод, в інших випадках він використовується для позначення як дружнього, так і недружнього поглинання.

Основним мотивуючим фактором злиттів і поглинань $є$ синергійний ефект, що виражається в створенні додаткової вартості від цього інтеграційного процесу. М\&A-трансакції поділяють на три види: горизонтальні (злиття двох конкурентів), вертикальні (об'єднання юридичних осіб, між якими існують чи можуть існувати правовідносини продавця і покупця) та конгломеративні (об’єднання компаній, які не є ні конкурентами, ні партнерами (покупцями, продавцями). Існує поділ M\&A на внутрішні (inbound), що передбачають придбання іноземною компанією національної компанії, та зовнішні (outbound) трансакції, коли національна компанія придбаває іноземну компанію. В Україні переважним чином відбуваються inbound M\&A.

Слід підкреслити, що рекомендації в рамках фінансового бізнес-консалтингу в умовах інтернаціоналізації фінансової сфери відносно використання операцій злиття та поглинання, що проведені 3 дотриманням вимог законодавства, а також прав та законних інтересів усіх учасників процесу є такими, що розглядаються як цілком прийнятні інструменти розвитку бізнесу в усьому світі.

Узагальнюючи аналіз тенденцій і закономірностей М\&А-трансакцій в умовах інтернаціоналізації фінансової сфери, можна зробити такі висновки:

- перспективність М\&А-угод визначається: можливістю залучення додаткових ресурсів, що сприятиме отриманню синергійного ефекту (взаємодоповнююча дія активів); зростанням якості управління та подоланням неефективності діяльності; географічним розширенням функціонування; особистими мотивами менеджерів;

- технологічно диверсифіковані іноземні компанії звичайно проникають на нові ринки через поглинання місцевих фірм;

- великі ТНК випереджають дрібніші компанії за кількістю M\&Aугод, хоча через зниження трансакційних витрат активізуються невеликі фірми;

- у випадку коли злиттями управляють технології і глобалізація економіки, а не бажання компаній домінувати на ринках і підвищувати 
ціни, можна говорити про позитивні наслідки (у першу чергу - ефект масштабу); інакше позитивні наслідки можуть бути короткостроковими й в основному на рівні самих підприємств;

- для обмеження негативних наслідки процесів M\&A і недопущення надмірної концентрації, антиконкурентної поведінки і підвищення цін, необхідним є контроль з боку держави, основними напрямами такого контролю в розвинених країнах мають бути: антимонопольне регулювання, ревізування операцій з цінними паперами, оптимізація оподатковування, бо від діапазону податкових виплат залежить і безпосередня вартість угоди злиття або поглинання.

\section{5. Висновки}

Фінансовий бізнес-консалтинг сприяе вирішенню таких основних завдань: формування фінансової політики; проведення фінансової експертизи; пошук джерел фінансових ресурсів; аналіз і підвищення поточної фінансової ефективності діяльності суб'єктів господарювання; зміцнення фінансового становища, досягнення фінансової стійкості і незалежності суб'єктів господарювання; оптимізація управління капіталом організації; оптимізація фінансових відносин з кліснтами і кредиторами, з господарюючими суб'єктами, державними органами; оптимізація управління податками, бухгалтерського та управлінського обліку; впровадження передових методів фінансового менеджменту в умовах невизначеності та ризиків.

У процесі інтернаціоналізації фінансової сфери розгортаються такі передумови фінансової нестабільності, що загострюють потребу в фінансовому бізнес-консалтингу: зміна валютних режимів; зростання обсягів міжнародних потоків капіталу, обсягів валютообмінних операцій, збільшення швидкості поширення інформації; якісні зміни у структурі міжнародних потоків капіталу, що спричинили мобільність капіталів; приналежність суб'єктів фінансового ринку до різних національних економічних систем, що збільшує рівень ризику фінансових операцій та зумовлює зростання нестабільності глобального фінансового простору.

В умовах інтернаціоналізації фінансової сфери актуалізується завдання досягнення фінансової безпеки держави, що визначає регуляторні правила. Отже, зростає потреба у консалтингу щодо аспектів фінансової безпеки всіх суб'єктів економіки: домогосподарства, підприємства та держави. 


\section{Список літератури:}

1. DUE DILIGENCE. URL: http://ukragencia.org/?page_id=110 (дата звернення: 25.10.2019).

2. Барановський O.І., Барановська В.Г. Сутність і різновиди фінансово-промислових корпоративних об'єднань. Вісн. ун-ту банк. справи Нач. банку Украӥни. 2008. № 3. С. 133.

3. Вітлінський В.В., Великоіваненко Г.І. Ризикологія в економіці та підприємництво. Монографія. Київ. КНЕУ, 2004. 480 с.

4. Білорус О.Г., Лук'яненко Д.Г. Глобалізація і безпека розвитку. Монографія. Київ. КНЕУ, 2001. 733 с.

5. Гранатуров В.М., Шевчук О.Б. Ризики підприємницької діяльності: проблеми аналізу. Київ : Зв'язок, 2000. 152 с.

6. Кокошинський В.В. Удосконалення теоретико-методологічних засад функціонування промислово-фінансових груп в системі регулювання економіки. Економіко-математичне моделювання сочіально-економічних систем. Київ, 2008. Вип. 13. С. 119-120.

7. Коломієць Г.М. Спряження невизначеності господарських систем та їх реформування : автореф. дис. ... д-ра екон. наук : 08.01 .01 / Г.М. Коломієць ; Харк. нац. ун-т ім. В.Н. Каразіна. Харків, 2004. 36 с.

\section{References:}

1. DUE DILIGENCE. URL: http://ukragencia.org/?page id=110 (in Ukrainian)

2. Baranovsjkyj O.I., Baranovsjka V.H. (2008). Sutnistj i riznovydy finansovopromyslovykh korporatyvnykh ob'jednanj [The essence and variety of financialindustrial corporate associations]. Visn. un-tu bank. spravy Nac. banku Ukrajiny, no. 3, p. 133. (in Ukrainian)

3. Vitlinsjkyj V.V., Velykoivanenko Gh.I. (2004). Ryzykologhija v ekonomici ta pidpryjemnyctvo [Riskology in Economics and Entrepreneurship]. Kyiv, 480 p. (in Ukrainian)

4. Bilorus O.Gh., Luk'janenko D.Gh. (2001). Ghlobalizacija i bezpeka rozvytku [Globalization and security of development]. Kyiv: KNEU, 733 p. (in Ukrainian)

5. Ghranaturov V.M., Shevchuk O.B. (2000). Ryzyky pidpryjemnycjkoji dijaljnosti: problemy analizu [Risks of entrepreneurship: problems of analysis]. Kyiv: Zv'jazok, 152 p. (in Ukrainian)

6. Kokoshynsjkyj V.V. (2008). Udoskonalennja teoretyko-metodologhichnykh zasad funkcionuvannja promyslovo-finansovykh ghrup v systemi reghuljuvannja ekonomiky [Improvement of theoretical and methodological foundations of functioning of industrial-financial groups in the system of regulation of economy]. Ekonomiko-matematychne modeljuvannja socialjno-ekonomichnykh system, vyp. 13, pp. 119-120. (in Ukrainian)

7. Kolomijecj Gh.M. (2004). Sprjazhennja nevyznachenosti ghospodarsjkykh system ta jikh reformuvannja [Confusion of uncertainty of economic systems and their reforming] (PhD Thesis), Kharkiv: V.N. Karazin Kharkiv National University. (in Ukrainian) 